\title{
The Effects of the Madeung Tradition on the Nutritional Status of Postpartum Mothers in Alue Waki, Aceh
}

\author{
${ }^{1}$ Arif Iskandar, ${ }^{2}$ Khori Suci Maifianti \\ ${ }^{1}$ Faculty of Public Health, Universitas Teuku Umar, Aceh, Indonesia \\ ${ }^{2}$ Faculty of Agriculture, Universitas Teuku Umar, Aceh, Indonesia \\ Coresponding author: Artif Iskandar, e-mail: arifiskandar@utu.ac.id \\ Co-author: KSM: Khori Suci Maifianti: khorism@utu.ac.id \\ Submitted:21/02/2021 Revised:24/03/2021 Accepted:01/04/2021 Published online: 06/04/2021
}

doi: https://doi.org/10.35308/j-kesmas.v7i2.1646. How to cite this article: Iskandar, A \& Maifianti, K.S. (2021). The Effects of the Madeung Tradition on the Nutritional Status of Postpartum Mothers in Alue Waki, Aceh. J-Kesmas: Jurnal Fakultas Kesehatan Masyarakat (The Indonesian Journal of Public Health).8(1): 7-11.

\begin{abstract}
The high level of public belief and trust in the madeung tradition as a treatment for postpartum mothers is still widely found in traditional Acehnese communities, especially the Raja Ubit family - an indigenous community in Blang Tripa. Postpartum mothers are required to practice the madeung tradition in the form of restrictions on consuming certain types of food, in which this tradition must be carried out for 44 days. The purpose of this study was to find out the effects of the practice of the madeung tradition on the nutritional status of postpartum mothers. This study applied a descriptive-analytic design with a cross-sectional approach. The number of respondents in this study was 20 people. The results of the chi-squared test, Fisher's exact test, and cross-tabulation between the nutritional status of postpartum mothers and the practice of the madeung tradition indicated the p-value of 0.545 (> 0.05). Therefore, it can be concluded that there is no significant influence between the nutritional status of postpartum mothers and the practice of the madeung tradition. Health officers from Alue Rambot Health Center are expected to run education programs for pregnant women about the good practice of the madeung tradition after the childbirth process based on health principles.
\end{abstract}

Keywords: Madeung Tradition, Nutritional Status, Postpartum Mothers.

\section{Introduction}

Nutrition plays an important role in fulfilling the quality of human resources. The government is currently highly focused on nutrition problems, especially related to the health of mothers and their babies in the first 1000 days of life. The first 1000 days of life begin when the fetus is still in the womb until the child is 2 years old (Indonesia's Ministry of Health, 2012). Atmarita (2005) conveyed the fact that the nutritional status of mothers can be found out by measuring the Body Mass Index (BMI). Based on data from Basic Health Research (2013), 20.8\% of women, aged 15 - 49 years, experience chronic energy deficiency (BMI < 18.5). Meanwhile, based on the data from the government of Aceh Province, about $20 \%$ of women of reproductive age experience chronic energy deficiency. Furthermore, based on the report of the 2017 Aceh Nutritional Status Monitoring, there are $1.9 \%$ of women of reproductive age in West Aceh who are at risk of suffering from lack of calorie energy (Health Office of Aceh \& Department of Nutrition of POLTEKKES KEMENKES Aceh, 2017).
The madeung tradition is a tradition practiced by Acehnese society. Those who practice this tradition are women who have just given birth. This tradition is carried out for 44 days with various kinds of prohibition and provisions that must be applied. One of the provisions is eating habits, such as eating rice mixed with dry, roasted fish. Furthermore, those women are also prohibited to eat eggs after giving birth (LAKA, 1990).

The madeung tradition is still believed and practiced among the people of Aceh. For indigenous peoples, especially in rural areas, this tradition is a must for women after giving birth or postpartum mothers. In the practice of this madeung tradition, those mothers are prohibited from consuming certain types of food. Types of food that should not be consumed by them include tuna, eggs, shrimp, shellfish, papaya, banana, chilies, and fruits that contain lots of water. This practice is feared because of having the potential to cause a lack of nutrition for postpartum mothers. Adequate nutritional intake is needed by them for recovery and preparation for breastfeeding. 
Postpartum mothers should have sufficient food intake to meet the nutritional needs of their babies. The food consumed by postpartum mothers will affect the quality of their breast milk in meeting the nutritional needs of babies. However, due to the necessity of practicing this madeung tradition, those postpartum mothers must follow rules in the form of restrictions on consuming certain types of food. This condition can result in a nutritional adequacy rate that is not fulfilled from the type of food eaten. In the end, this will affect the nutritional status of the mother. Therefore, it can impact the optimal process of growth and development of babies, especially their first 1000 days of life (Harnany, 2006).

Apart from the Acehnese in rural areas in general, the people at the foothill of Mount Kong, Blang Tripa Village, Alue Waki are the indigenous people of the Raja Ubit family who still strictly practice the madeung tradition. Raja Ubit family is a community that used to live in the area of the Gunong Ijoe mountains. After the Indonesian government and GAM are in peace in 2005, some of them moved and inhabited Blang Tripa. The indigenous people in Blang Tripa still practice the madeung tradition based on experiences that are passed down by their ancestors. To date, this practice is still conducted by mothers who just give birth or postpartum mothers. However, some people in the community already have an open mindset along with the development of science and technology. Therefore, in carrying out the practice of the madeung tradition, they still pay attention to the adequacy of the nutrients from the food they eat.

Based on the illustration presented above, the purpose of this study is to find out the effects of the practice of the madeung tradition on the nutritional status of postpartum mothers in the Raja Ubit community in Blang Tripa, Alu Waki, Nagan Raya, Aceh.

\section{Methods}

The type of this study was a descriptive-analytic design with a cross-sectional approach. In this study, researchers collected the data of the dependent variable (nutritional status) and the independent variable (the practice of the madeung tradition) at the same time. Samples were taken using the total sampling technique, in which they were all mothers who were practicing and had practiced the madeung tradition from Blang Tripa Village, Alue Waki, Nagan Raya, totaling 20 people.

Primary data were collected by conducting interviews using a questionnaire containing the identity of the respondent, the question related to the madeung tradition, and measuring body weight using scales and height using the microtoice for finding out the nutritional status of postpartum mothers.

Meanwhile, the secondary data were obtained from the cooperation of related parties at the village and district governments and were also obtained from several sources of literature and articles.

\section{Results}

Table 1 below indicated that the average body weight (BW) of the respondents in this study was $54.2 \mathrm{~kg}$, its median was $52.50 \mathrm{~kg}$, the lowest was 38 $\mathrm{kg}$, and the highest was $70 \mathrm{~kg}$. Meanwhile, the average body height (BH) of them was $149.7 \mathrm{~cm}$, its median was $149 \mathrm{~cm}$, the lowest was $138 \mathrm{~cm}$, and the highest was $158 \mathrm{~cm}$. In addition, the average age of them was 30 years, its median was 29.50 years, the lowest was 22 years, and the highest was 40 years. Furthermore, the average value of body mass index (BMI) of them was 24.36, its median was 23.14, the lowest was 18.42, and the highest was 32.6. Other than that, the average score for the practice of the madeung tradition was 9 , its median was 9 , the lowest was 5, and the highest was 15 .

Table 2 below showed an overview of the nutritional status of the respondents which was divided into normal and abnormal nutritional status. Normal nutritional status is obtained from the value of Body Mass Index (BMI) categorized as good nutritional status, while abnormal nutritional status is taken from the value of Body Mass Index (BMI) categorized as poor nutritional status, undernutrition status, and over nutritional status/obesity. Based on the results of descriptive analysis, respondents with abnormal nutritional status were 6 people (30\%), while those with normal nutritional status were 14 people $(70 \%)$. Apart from that, respondents in the good category of the practice of the madeung tradition were 12 people (60\%), while those in the poor category were 8 people $(40 \%)$.

Based on Table 3 below, the results of the chisquared test, Fisher's exact test, and cross-tabulation between the nutritional status of postpartum mothers and the practice of the madeung tradition indicated the p-value of 0.545 (> 0.05). Therefore, it can be concluded that there is no significant influence between the nutritional status of postpartum mothers and the practice of the madeung tradition. 
Table 1. Results of Descriptive Analysis of Respondents' Characteristics (NumericalData)

\begin{tabular}{llllll}
\hline Respondents' Characteristics & Mean & Median & SD & Min & Max \\
\hline Body Weight $(\mathrm{BW})(\mathrm{kg})$ & 54.20 & 52.50 & 8.433 & 38 & 70 \\
Body Height $(\mathrm{BH})(\mathrm{cm})$ & 149.70 & 149.00 & 5.741 & 138 & 158 \\
Age & 30.15 & 29.50 & 6.302 & 22 & 40 \\
Body Mass Index (BW/BHxBH) & 24.36 & 23.14 & 4.24 & 18.42 & 32.76 \\
Score for the Practice of the Madeung Tradition & 9.00 & 9.00 & 2.734 & 5 & 15 \\
\hline
\end{tabular}

Primary Data: Self-Processed, 2020

Table 2. Results of Descriptive Analysis of Respondents' Characteristics (Categorical Data)

\begin{tabular}{lrr} 
Respondents' Characteristics & N= 20 & Percentage (\%) \\
\hline Nutritional Status & 6 & $30 \%$ \\
$\quad$ Normal & 14 & $70 \%$ \\
$\quad$ Abnormal & & \\
The Practice of the Madeung Tradition & 12 & $60 \%$ \\
$\quad$ Good & 8 & $40 \%$ \\
$\quad$ Poor
\end{tabular}

Primary Data: Self-Processed, 2020

Table 3. Results of the Analysis of the Effects of the Madeung Tradition on the Nutritional Status of Postpartum Mothers

\begin{tabular}{|c|c|c|c|c|c|c|}
\hline \multirow{3}{*}{$\begin{array}{l}\text { The Practice of } \\
\text { the Madeung } \\
\text { Tradition }\end{array}$} & \multicolumn{4}{|c|}{ Nutritional Status } & \multirow{3}{*}{ Total } & \multirow{3}{*}{$p$-value } \\
\hline & \multicolumn{2}{|c|}{ Abnormal } & \multicolumn{2}{|c|}{ Normal } & & \\
\hline & $\mathrm{n}$ & $\%$ & $\mathrm{n}$ & $\%$ & & \\
\hline Practicing & 4 & 33,3 & 8 & 66,7 & 12 & 0.545 \\
\hline Not Practicing & 2 & 25,0 & 6 & 75,0 & 8 & \\
\hline Total & 6 & 30,0 & 14 & 70,0 & 20 & \\
\hline
\end{tabular}

Primary Data: Self-Processed, 2020

\section{Discussion}

Based on the data collected in this study, it indicated that some postpartum mothers still practice the madeung as a tradition that has been carried out from generation to generation. This tradition prohibits postpartum mothers from consuming certain types of food, such as fish, meat, eggs, spicy foods, some vegetables, and fruits. This prohibition is carried out because they have the belief that it can help the healing process of wounds caused by childbirth. However, this practice may make the nutritional intake of those mothers not be fulfilled properly. In this study, it was also found that some respondents had carried out modern ways of practicing the madeung tradition, namely by still paying attention to balanced nutritional intake. A good individual nutritional intake is certainly able to meet the nutritional needs required by the body. Fulfillment of balanced nutritional needs serves to maintain the individuals' body stability, thereby still in a healthy state physically and mentally. In addition, it is also able to run the reproductive system and metabolic system based on its function in a healthy body condition (Marmi, 2013). The analysis of the characteristics of the postpartum mothers in Blang Tripa Village, Alue Waki can show the level of diversity of each respondent. From the data of respondents' characteristics, it is able to provide an overview of the condition of the mothers who are conducting and have conducted the madeung tradition.

The results of this study showed p-value of 0.545 , so it can be concluded that the practice of madeung has no effect on the nutritional status of the mother. This study are in line with a study conducted by ZA and Juwita (2017) that there is no relationship between nutritional status and dietary restrictions after childbirth $(\mathrm{P}=0.365)$.

From the results obtained, it is different from the assumption that the restrictions on consuming certain 
types of food will affect the nutritional status of the postpartum mother. Some kinds of food that are prohibited, such as fish (Catfish, rays, marang, \& tuna), shellfish, shrimp, eggs, and salted fish, indeed may cause itching. Meanwhile, some types of vegetables are also prohibited to be eaten, such as cabbage, kale, jackfruit, and mustard greens. These vegetables contain gas and are considered to cause flatulence to the postpartum mother, which ultimately affects the stomach of the baby. In addition, fruits that contain water, such as watermelon, papaya, oranges, and pineapples, are also prohibited to be consumed because they are assumed to result in a long uterine healing process of the postpartum mothers.

Meanwhile, freshwater fish, fruits, and vegetables outside the prohibited foods can still be consumed. All mothers who are giving birth in the Raja Ubit family from Blang Tripa practice the madeung tradition. This tradition has been carried out from generation to generation by the Acehnese. People believe that this tradition can maintain the quality of the postpartum mothers' beauty after childbirth and can shrink the stomach so that the shape of their body becomes slim and their body scent becomes fragrant.

By considering the health aspect, although the practice of the madeung tradition does not affect the nutritional status as seen in this study, it is still necessary to make changes in the tradition that prohibit eating some kinds of food and drink. For example, the restrictions of drinking water can result in dehydration or lack of fluids in the body of mothers and babies. Likewise, foods that contain important nutrients, such as protein in fish, meat, and eggs, are highly needed by the body. This also applies to fruits and vegetables, which are important to eat because of containing vitamins, minerals, and fiber that can help to defecate. Food intake is highly important for maternal nutrition and affects breast milk in meeting the nutritional needs of infants. The problem of malnutrition is mostly due to the presence of a false belief in the society regarding the relationship between beliefs on certain kinds of food and the health condition (Foster \& Anderson, 2006). According to Lowenberg (1986), eating habits are the kind of habits that will not change quickly if the food has a deep meaning.

Based on a study conducted by Deri (2009) on the food consumption patterns of postpartum mothers who carry out the badapu tradition in Aceh Singkil, it indicated that $100 \%$ of the postpartum mothers consume rice as the main source of carbohydrate and only $13.3 \%$ of them consume other foods as an additional energy source. Therefore, it is possible for some postpartum mothers (73.4\%) to experience a lack of energy and nutrients due to restrictions on consuming those foods.

Maternal nutritional needs are not only about their nutritional status but also about the need for infant development and maternal health. Danone Institute (2013) explained that balanced nutrition is a condition of food that is regulated daily based on the types of nutrients containing in the food and the needs of the individual. The madeung tradition in the Raja Ubit family from Blang Tripa Village has become a culture and part of community life. Some cultures and customs in society are beneficial. However, some of them may be harmful. Therefore, education should be carried out slowly so that the practice of the madeung tradition as a health treatment is in line with the public health paradigm.

\section{Conclusion}

In the Raja Ubit family, an indigenous community in Blang Tripa, there are some postpartum mothers who still practice the madeung tradition, in which this tradition has been carried out from generation to generation. The results of statistical tests showed that there was no significant effect between the practice of the madeung tradition and the nutritional status of the postpartum mothers. The madeung tradition should not be abandoned, but this tradition can still be carried out by adjusting it with the nutritional principles recommended in the study of health science. The head of the Health Office of Nagan Raya Regency can provide continuous educational programs for couples of childbearing age, pregnant women, and community leaders in the circle of the Raja Ubit family about the good practice of the madeung tradition after the childbirth process based on health principles.

\section{Acknowledgment}

The researchers would like to thank all those involved in helping the research process, indigenous community leaders, respondents (mothers who were conducting and had conducted the madeung tradition), traditional midwives, and professional midwives in the research area. 


\section{Authors' Contributions}

All researchers contributed to this study, starting from collecting and analyzing data until compiling the manuscript. The first author is the main researcher, while the second author is a researcher who helps the research process.

\section{Refferences}

Atmarita, (2005). Nutrition Problems in Indonesia, in Integrated International Seminar and Workshop on Lifestyle - Related Diseases. Gajah Mada University: Yogyakarta.

Danone Institute, (2013). Tentang Gizi Seimbang., Retrieved November 14, 2020, Available http:/www.danonenutrindo.org/gizi_seimbang.p hp

Depkes RI, (2012). Rencana Kerja Pembinaan Gizi Masyarakat Tahun 2013, Direktorat Bina Gizi: Jakarta.

Deri, F. (2009). Kajian Konsumsi Makanan Tradisi Badapu dan Status Gizi Ibu Nifas di Kecamatan Singkil Kabupaten Aceh Singkil. Tesis. Fakultas Kesehatan Masyarakat Universitas Sumatra Utara, Medan.

Dinkes Aceh dan Poltekkes Kemenkes Aceh., (2017). Laporan Pemantuan Status Gizi Tahun 2017. Jurusan Gizi Poltekkes Kemenkes Aceh. Banda Aceh.
Foster, GM \& Anderson, BG., (2006). Antropologi Kesehatan, UI Press: Jakarta

Harnany, AS. (2006). Pengaruh Tabu Makanan, Tingkat Kecukupan Gizi, Konsumsi Tablet Besi dan Teh Terhadap Kadar Hemoglobin pada Ibu Hamil di Kota Pekalongan Tahun 2006. Tesis. Universitas Diponegoro, Semarang.

Lembaga Adat dan Kebudayaan Aceh, (1990). Pedoman Umum Adat Aceh Edisi I. LAKA Propinsi Daerah Istimewa Aceh: Banda Aceh.

Lowenberg, M, E,. Todhunter, E, N., Wilson, E.D,. Feeney, M. C,. \& Savage, J. R, (1968). Food \& Man, New Yor; Wiley Eastern Private Limited.

Marmi, (2013). Gizi Dalam Kesehatan Reproduksi. Pustaka Belajar: Yogyakarta.

Riskesdas., (2013). Laporan Nasional Riset Kesehatan Dasar (Riskesdas Tahun 2013). Badan Penelitian dan Pengembangan Kesehatan Departemen Kesehatan RI: Jakarta.

ZA, RN, \& Juwita, CM., (2017). Faktor-faktor yang Berhubungan Dengan Pantangan Makanan Selama Masa Nifas di Desa Tibang Kecamatan Syiah Kuala Banda Aceh, Journal of Healthcare Technology and Medicine Vol.3 No.2 Oktober, e-ISSN : 2615-109X, Universitas Ubudiyah Indonesia. Banda Aceh 